\title{
Effective integration of SMS communication into a distance education accounting module
}

\author{
AA van Rooyen \\ Department of Financial Accounting \\ University of South Africa
}

\begin{abstract}
The University of South Africa (Unisa), as a distance education institution, is continuously challenged to lessen the negative impact distance has on students' learning. The effective use of technologies affords distance education institutions with valuable opportunities to enhance teaching and support students' learning. Using online technologies in the context of a developing country like South Africa often remains unrealised because of the persistent impact of lack of access, bandwidth and cost to students. Most students, however, have mobile phones, thus creating an ideal opportunity for distance education institutions to increase the effectiveness of learning.

This article investigated students' responses to a pilot study aimed at integrating short message systems (SMSs) into the study experience of accounting students at Unisa. This research found that students overwhelmingly experienced this initiative not only as support but also more importantly as assistance to enable them to study more effectively. On the basis of the evidence provided, it is evident that using mobile technology can enhance the learning experience of accounting students and provide them with a more satisfying and successful experience.
\end{abstract}

Key words

Accounting; distance education; mobile learning; short message system (SMS); student support

\section{Introduction}

Higher education in general and educators at distance learning institutions in particular are constantly challenged to increase the effectiveness of their teaching by improving student retention and throughput. One of the strategies available, especially for distance education institutions, is the effective integration of different technologies in their teaching. The success of students and the institution depends not only on the quality of the learning package, but also on the quality and scope of the support given to the student. Many students at distance education institutions, including Unisa, are often alienated and discouraged by negative (and unsuccessful) experiences in their engagement with distance 
education. High-risk modules, such as those in accounting, demand special intervention for those students trapped in perpetual failure cycles. The better the support for students and the easier their access to it, the less likely they will be to consider dropping out.

The main mode of teaching delivery at Unisa is printed study material, although the University has recently launched several initiatives to increase the effective use of technologies. With the increasing availability of mobile devices, there has been a shift in higher education from delivering information and study material in the print medium only towards the use of mobile devices. Higher education institutions use mobile devices to supply their students with information about timetable changes, assessment deadlines and other urgent administrative details (see Keegan 2005:67). In addition to administrative support, research by Barker, Krull and Mallinson (2005:17) confirms that wireless technologies in education have an impact on motivation, which results in benefits for students. In a technology-mediated study (Lillie 2008:267), positive feedback was received from auditing students on the use of technology tools. According to Zawacki-Richter, Brown and Delport (2007:20) innovative faculty teachers should consider adopting mobile learning because mobile technologies afford new opportunities for both teaching and learning.

Mobile technologies provide an affordable and easily accessible technology that lecturers can use effectively to assist accounting students with their studies. The popularity of SMS (short message service) messaging among students provides opportunities to exploit the possibilities of using SMS for teaching and learning (Ng'ambi 2005:116). The University of Pretoria started using SMS for support in 2002 in three paper-based distance education programmes (Keegan 2005:68). A research project undertaken at the University of Cape Town has given some insight into the way mobile devices can be used effectively at a minimum cost to assist educators in student support (Ng'ambi 2005:119). Mobile support has the potential to improve students' success rates and enhance the quality of the learning experience.

This article reports on a pilot study undertaken at Unisa in 2006 and 2007 to determine how mobile phones could be used effectively to guide second-year Accounting (ACN202R) students through their studies, communicate with the students on a regular basis, motivate them and ensure that they received important information. The following hypothesis was tested in this research: Does receiving SMSs from the lecturer assist students with their learning? The data may assist in the planning of more effective learning interventions, which will have a positive impact on students' retention rate.

\section{Literature review}

Students' departure from higher education institutions is not a new problem. Many retention efforts have failed because of an inability to understand exactly why students leave (Tinto 1998:167). Researchers agree that the causes of retention are complex, but the absence of sufficient contact with members of the institution is at the top of the list of factors that affect the retention rates of students (Astin 1997:40; Berger \& Braxton 1998:116; Freeman, Hall \& Bresciani 2007:768).

Through the support of technologies, student success rates could be improved and the quality of the learning experience enhanced (Barker et al. 2005:22; Stone 2005:183; De Lange, Suwardy \& Mavondo 2003:10). Most institutions concur that distance education students need better support to boost their confidence and enable them to work properly. 
The diverse group of distance education students in the South African context have one thing in common - a mobile phone (Louw 2005:104). The current advances in mobile technology could enable the formation of learning environments enriched by this technology - hence the need to reconceptualise learning for the mobile age. Mobile phone networks extend to rural areas (Sharples, Taylor \& Vavoula 2005; Brown 2004; Barker et al. 2005:17) and allow people in rural communities not only to make phone calls but also to enjoy the benefits of mobile services such as text and multimedia messaging. Mobile technologies enable people to communicate regardless of their location.

Mobile phones allow people to communicate by means of SMS, and communication is a vital element in distance education. Louw (2005:103) quotes Dhanarajan (1996) as follows: "A course is much more than a package of study materials ... they (the students) must be supported in various ways. They may be distant from their teaching institution, but they must not be isolated." Louw comments that one of the most effective means of support in the distance learning environment is to make contact with the student - anything that will bring the lecturer and the student closer together so that there can be a "meeting of minds" (Louw 2005:103). She is of the opinion that if a student receives an SMS from the university at which he or she is enrolled, he or she would probably feel excited about being part of this new adventure called learning. Louw (2005:104) goes on to say that a distance education institution should

help its students by minimising the effects of isolation

$\square$ minimise the dropout rate

$\square$ improve the students' learning experience

Distance education, e-learning and mobile learning are all terms relating to modern education. They denote an integration of information technologies and communication tools to support educational professionals in remote teaching (Shih \& Hung 2007:1; Traxler \& Leach 2006:98-102). Technology changes what we do and what we can do. This is especially applicable to teachers and students. Over the past few years a trend has emerged in applying emerging technologies to support learning in ever more challenging situations (Mildrad, Spector \& Davidsen 2003:13; De Lange et al. 2003:1). These technologies can reach students who would not otherwise have the opportunity to participate in education (Colley \& Stead 2005:57; Stead 2005:153-156). The use of technologies is beginning to have a positive effect on teaching because it has an impact on student retention and achievement (Bates 2000:21; De Lange et al. 2003:1-14; Kukulska-Hulme \& Pettit 2009:135-156; Joshi \& Chugh 2009:1-10).

Keegan (2005) defines mobile learning as the provision of education on mobile phones. Mobile learning happens across locations or takes advantage of learning opportunities offered by portable technologies. The term "mobile learning" is increasingly being applied to the use of small, portable, handheld electronic devices used for educational activities (Traxler \& Leach 2006:98; Stead 2005:153). Since e-learning is the macro concept that includes online and mobile learning environments, mobile learning can be viewed as a subset of e-learning (Zawacki-Richter et al. 2007:3). The world of education and training is divided into two halves known as conventional education and distance education. Conventional education is referred to as traditional or face-to-face education. Mobile learning is a subdivision of distance education and is a rich form of education and training provision on mobile phones (Keegan 2005:66; Zawacki-Richter et al. 2007:3). Mobile 
technology affords users the opportunity to communicate among themselves and develop collaborative learning.

There is little data on the use of mobile phones in accounting education. There are only a few systematic literature reviews and most of the studies are merely descriptive. Studies note problems with the technology, such as poor battery life or small screens, but students seem to enjoy using mobile phones (Sandars 2006:551). A study by Trifonova (2003) describes the use of mobile phone messages for matters such as lecture times or examination results. In a study conducted by Horstmanshof (2004), the two-way exchange of messages between tutors and students was noted as being effective. Feedback from students in mobile learning project trials has indicated that users enjoy the content and love the collaboration (Colley \& Stead 2005:57). According to Sandars (2006), the high level of mobile phone use among undergraduate students suggests that they are unlikely to avoid the use of mobile phones. In an experiment on the use of SMS to support the learning of new English words, students expressed their satisfaction with and enjoyment of learning with the help of their mobile phones and SMSs (Cavus \& Ibrahim 2009:88).

\section{Background to the study}

It takes the average Unisa student nine years to complete a degree and only about $15 \%$ of students persevere to the end (Louw 2005:104). Students at Unisa must enrol for ACN202R as part of the prescribed curriculum for a Bachelor in Accounting Science (BCompt). Almost $50 \%$ of students registered for ACN202R have failed the module at least once. A study by Prinsloo and Van Rooyen (2007:57) in 2004 found that of the students registered for ACN202R, $61.37 \%$ had registered for ACN202R for the first time, while $58.91 \%$ had registered for the module more than once. Face-to-face interventions such as group discussions afford students the opportunity to attend sessions with the course lecturer. Group discussions were held in Pretoria, Durban and Cape Town in 2004, but less than $22 \%$ of the respondents in the 2004 survey indicated that they had attended the group discussions (Prinsloo \& Van Rooyen 2007:58). The reasons for nonattendance varied from logistical concerns to difficulty obtaining time off from employers.

ACN202R is identified as a high-risk module. A module is considered to be high risk when it has a withdrawal rate of $30 \%$ or greater for several academic terms (Student Academic Resource Center 2009:1). Students generally have to pass these high-risk modules in order to pursue a particular major, as in the case of ACN202R.

As part of a broader strategy, a project was launched to investigate students' perceptions of the use of mobile technologies in supporting them in their studies. Using a mobile phone to enhance learning is practical at Unisa because almost all students have access to one. It is also relatively cheap - an SMS costs less than 20 cents to reach a student through the University's Learning Management System. The fact that most students in ACN202R have a mobile phone creates a number of opportunities to enrich teaching and learning. Research has shown that almost $70 \%$ of students registered for the ACN202R module are between the ages of 20 and 30 (Prinsloo \& Van Rooyen 2007:56). In 2009, the number increased to nearly $72 \%$.

According to Hollands (2006), sending text messages has become the "cool way to communicate" and the ubiquitous abbreviations and accompanying lack of punctuation now come automatically to many in the younger generation. The mobile phone interventions, which consisted of two distinct phases, started in 2006. The first phase entailed drawing up 
12 SMS messages that could be sent to students over a 14-week period. In 2006, the content of the ACN202R module consisted of four topics, namely group financial statements, financial analysis, time value of money and valuations. The difficulty levels of the topics, the number of pages per topic and the due dates for assignments were taken into consideration when the ACN202R lecturers compiled the 12 SMSs. An SMS was sent once a week, on Monday mornings, informing students which section of the study material needed to be covered during the following week. In some instances, two weeks were allocated for more difficult and complex sections of the syllabus. SMSs of 160 characters or fewer were sent to registered students' cell phone numbers, which were available on their student accounts. The lecturers compiled these 12 SMSs in SMS language.

ACN202R is a semester module. The first pilot project was completed during the fivemonth cycle from June to October 2006, with 2197 students writing their examination on 16 October 2006. The second pilot period, in the same module, ran from January to May 2007, and the 2669 students wrote their examination on 30 May 2007. The third pilot project ran from June to October 2007, and the 2426 students wrote the examination on 15 October 2007. In all three semesters, the first SMS was sent a week after registration closed and the last SMS a few days before the examination.

Students registered for the module received three types of SMS from their lecturers namely an informational, motivational or academic support SMS, as set out in table 1:

Table 1: SMSs sent to ACN202R students

\begin{tabular}{|c|c|c|}
\hline $\begin{array}{c}\text { SMS } \\
\text { number }\end{array}$ & Type of SMS & Wording of SMS \\
\hline 1 & Informational & $\begin{array}{l}\text { Welcome } 2 \text { ACN202! Lecturers will SMS u every week with workload for that } \\
\text { week. U need } 2 \text { have text book and financial calculator. }\end{array}$ \\
\hline 2 & $\begin{array}{l}\text { Academic and } \\
\text { informational }\end{array}$ & $\begin{array}{l}\text { ACN202. Let's do pages } 1-42 \text { of guide this week. Do as many exercises as } \\
\text { possible-do not just read thru text. Guide is available on myUnisa. }\end{array}$ \\
\hline 3 & $\begin{array}{l}\text { Academic and } \\
\text { informational }\end{array}$ & $\begin{array}{l}\text { ACN202. Next } 2 \text { weeks work on pages } 43-83 \text { of guide. Plse submit } 1^{\text {st }} \\
\text { assignment be } 4 \text { 14/8. U can submit via myUnisa. }\end{array}$ \\
\hline 4 & $\begin{array}{l}\text { Academic and } \\
\text { motivational }\end{array}$ & $\begin{array}{l}\text { ACN202.This week work thru pages } 84-101 \text {. Hope u're still on schedule. U're } \\
\text { not on your own-there are } 2500 \text { students doing this module with } u \text {. Ur family } \\
\text { and friends } r \text { proud of } u \text {. }\end{array}$ \\
\hline 5 & $\begin{array}{l}\text { Academic and } \\
\text { informational }\end{array}$ & $\begin{array}{l}\text { ACN202. This week we're doing pages } 102-142 \text { and next week } 143-172 \text {. Start } \\
\text { questions } 1 \text { to } 4 \text { of assign } 2 \text {. Practice makes perfect! }\end{array}$ \\
\hline 6 & Academic & $\begin{array}{l}\text { ACN202. This week do pages } 173-227 \text { and Q5 from assign2. U can also do } \\
\text { Q1 to Q6 in tut letter } 101 \text { page } 53 .\end{array}$ \\
\hline 7 & Academic & $\begin{array}{l}\text { ACN202. This week Topic B. Guide pages } 228-249 \text { and text book pages 1-84. } \\
\text { Summarize formula on A4 paper and learn every day. }\end{array}$ \\
\hline 8 & $\begin{array}{l}\text { Academic and } \\
\text { informational }\end{array}$ & $\begin{array}{l}\text { ACN202. This week Topic C. Guide pages } 250-260 \text { and text book } 85-129 \text {. U } \\
\text { must use either tables, formula or calculator in exam. }\end{array}$ \\
\hline 9 & Academic & $\begin{array}{l}\text { ACN202 - last topic this week. Topic D. Guide pages } 261-285 \text { and text book } \\
\text { 130-228. Do Q1 to Q5 from assign 3. }\end{array}$ \\
\hline 10 & Academic & $\begin{array}{l}\text { ACN202. Start revision. Work thru Q1 to Q11 in tut letter } 101 \text { page } 53 \text {. Do not } \\
\text { look at answer b4 Q complete. Mark. Must complete within available time. }\end{array}$ \\
\hline 11 & Academic & $\begin{array}{l}\text { Work thru as many ACN202 questions as possible these last } 2 \text { weeks. } \\
\text { Everyday } 1 \text { question from each topic. Learn your formula. Practise, practise! }\end{array}$ \\
\hline 12 & Motivational & $\begin{array}{l}\text { Good luck with ACN202 exam Monday. U've come a long way-u can do it!! Do } \\
\text { all questions! Show all calculations. Rather write } 2 \text { much than } 2 \text { little. }\end{array}$ \\
\hline
\end{tabular}




\section{Methodology}

The pilot study entailed compiling a questionnaire (appendix A) and sending it to students registered during the third pilot period. Ethical clearance and permission for this study were obtained from the head of department. A covering letter attached to the questionnaire stated the aim of the research for the students and guaranteed their anonymity. Since previous research findings indicated that not all ACN202R students have access to emails (Prinsloo \& Van Rooyen 2007:68), it was decided to send the questionnaires by mail instead. The questionnaire was included in a tutorial letter sent to students at the end of the semester. The purpose of the questionnaire was to establish the answers to the following questions:

$\square$ Did students receive the SMSs?

Why did students not receive the SMSs?

$\square$ Could students finish the workload given in every SMS in the particular week?

Did the SMSs assist students with their studies?

Would a reply SMS to lecturers be helpful?

$\square$ Did students have a problem with the SMS language used?

Was the first SMS sent at a good time?

The questionnaire was compiled and sent to all 2963 students registered for the module ACN202R in the second semester of 2007. An extremely low percentage of questionnaires was returned - only 230 (less than $8 \%$ ). The results of this pilot study cannot therefore be used to make generalised assumptions about the whole study population. According to Benke and Street (1992:39), the results should therefore only be viewed as tentative because the response rate to the questionnaire was below $80 \%$. However, the data gathered from the returned questionnaires do provide some insight about a small part of the whole study population. The returned questionnaires were analysed and students' responses coded. An academic outside the Department of Financial Accounting verified the results. As an additional source of information, student emails and postings on the discussion forum were also analysed, coded and verified.

\section{Analysis and discussion of the questionnaire results}

In this discussion, the sequence of the questions in the questionnaire is followed. A remarkable $95.15 \%$ of the students indicated that they did have a cell phone (Question 1) and $90 \%$ of them did receive the SMSs (Question 2). The reasons advanced for students not receiving the SMSs were that either their mobile phone number was not on the Unisa system or their mobile phone number had changed during the semester and they had not updated their personal information (Question 3).

More than $60 \%$ of the respondents indicated that they could cope with the workload indicated per SMS, while $23.85 \%$ felt that there was too much work for the week (Question 4). Previous research had found that almost $35 \%$ of the study population of ACN202R was full-time students (Prinsloo \& Van Rooyen 2007:56). Part-time students were more likely to feel a need for less work per week than their full-time counterparts.

Just over $80 \%$ of the respondents indicated that they had benefited from the SMSs (Question 5), while $89.50 \%$ indicated that they would like to communicate with their lecturers by sending a reply message to them (Question 6). In 2007, the Unisa system could 
not accommodate reply SMSs of this kind. As a result of the findings of this research project, the Unisa system was updated and a trial run implemented for ACN202R students to send SMSs to the ACN202R lecturers during the first semester of 2009.

Of the respondents, $88.18 \%$ indicated that they could understand the SMS messages (Question 7), while 18.72\% indicated that lecturers should send the first SMS a week later, with 7.76\% opting for the first SMS two weeks later (Question 8).

Data gathered from emails sent to the lecturers confirmed the above data. Twelve emails were received in the period June 2007 to October 2007. None of the emails received by the lecturers with regard to the SMSs was negative. Extracts from the emails received from students are provided below. The extracts are direct quotes and the grammar and spelling errors have not been corrected. The quotes are anonymous:

\begin{tabular}{l}
$\begin{array}{l}\text { "Used the smsls, found them very motivating_an excellent guide } 4 \text { keeping on track with my } \\
\text { studies" }\end{array}$ \\
\hline "SMS ws gr8 help. It cut down planning time" \\
"SMS kept me reminded of my schedule and it provided a standard to measure progress. \\
Before the exam it was amusing" \\
\hline "Thank you for the weekly sms's - they are a great help!" \\
\hline "Thank you for the sms send today. I feel motivated, and even looking forward to picking up my \\
ACN202 books with all the support! It is nice to know the lecturers are behind us"
\end{tabular}

Students also commented on the use of the SMSs on the ACN202R discussion forum on the myUnisa webpage during the period June 2007 to October 2007. An extract from the discussion forum is provided below. The extract includes direct quotes and grammar and spelling errors have not been corrected. The quotes are anonymous:

\begin{tabular}{|l|l|}
\hline Student A & $\begin{array}{l}\text { "Thank you for the ACN202 lecturer sms! I think it's a wonderful idea and definitely } \\
\text { think the other modules should consider doing this as well. I feel more connected } \\
\text { and driven. It is very much appreciated, thank you!" }\end{array}$ \\
\hline Student B & $\begin{array}{l}\text { "Yha! Guys the lecturers sms's are inspiring they really keep us strong even though } \\
\text { im behind their schedule" }\end{array}$ \\
\hline Student A & "I am a little behind schedule, but still going strong!" \\
\hline Student C & "How many of you are still keeping up? just reply yes or no" \\
\hline Student D & "The lecturer sms's - wow, they fantastic! I feel quite motivated" \\
\hline Student E & "I also like receiving the sms's" \\
\hline Student F & $\begin{array}{l}\text { "I agree fully, this is the only course where I feel motivated to study, and I can feel } \\
\text { the lecturer' support" }\end{array}$ \\
\hline
\end{tabular}

\section{Conclusion}

The aim of this pilot study was to investigate the way mobile phones could be used in an accounting module at Unisa to guide students through their studies and in so doing, provide a more satisfying experience. In the light of the number of variables outside of the control of students and the institution in a distance education setting (Prinsloo \& Subotzky 2009), it was impossible to prove any direct relationship between this pilot project and student success. On the basis of the evidence provided, the use of mobile technology can enhance the learning experience of accounting students and provide them with guidance, motivation and the "personal touch", so often missing in distance education. This study pointed to the possibility of reaching a greater percentage of students than through the traditional group discussions. Since the majority of students have a mobile phone, lecturers could focus on 
the effective use of this technology. By supporting and guiding students with the use of mobile technologies, it may be possible to increase student success and retention. In this study, access to other technologies was not investigated, but the effective use of technologies could become an integral part of the future learning approach in accounting education at Unisa. Further research would be required to investigate the sustainability of SMSs in other accounting modules at Unisa and the scale to which these could be implemented.

\section{Bibliography}

Astin, A.W. 1997. How "good" is your institution's retention rat? Research in Higher Education, 38(6):647.

Barker, A., Krull, G. \& Mallinson, B. 2005. A proposed theoretical model for m-learning adoption in developing countries. Conference proceedings: Mobile technology: the future of learning in your hands, 4th World Conference on mLearning, October 25 to 28, Cape Town, South Africa. mLearn.

Bates, A.W. 2000. Lessons in the application of educational technologies in South Africa. http://www.saide.org.za/Resources/registrationforms/Lessons\%20in\%20Application $\% 2$ 0of\%20Technologies.pdf. Accessed: 10 September 2009.

Benke, R.L. \& Street, D.L. 1992. Accounting education research methodology. Accounting Education, 1(1):33-45.

Berger, J.B. \& Braxton, J.M. 1998. Revising Tinto's interactionalist theory of student departure through theory elaboration: Examining the role of organizational attributes in the persistence process. Research in Higher Education, 39(2):103-119.

Brown, T. 2004. Exploring future learning paradigms: Will m-learning survive. Conference proceedings: Conference keynote address: Mobile learning anytime everywhere, July 5 to 6, Rome, Italy. mLearn 2004.

Cavus, N. \& Ibrahim, D. 2009. m-Learning: An experiment in using SMS to support learning new English language words. British Journal of Educational Technology, 40(1):78-91.

Colley, J. \& Stead, G. 2005. Mobile learning = collaboration. Conference proceedings: Mobile learning anytime everywhere, 2004 mLearn Conference, July 5 to 6, Bracciano, Rome. Learning and Skills Development Agency.

De Lange, P., Suwardy, T. \& Mavondo, F. 2003. Integrating a virtual learning environment into an introductory accounting course: Determinants of student motivation. Accounting Education, 12(1):1-14.

Freeman, J.P., Hall, E.E. \& Bresciani, M.J. 2007. What leads students to have thoughts, talk to someone about, and take steps to leave their institution? College Student Journal, 41(4):755-770.

Hollands, B. 2006. Is dis da future of English? http://www.weekendpost.co.za/main/2006/04/22/news/nl103_22042006.htm. Accessed: 25 January 2008. 
Horstmanshof, L. 2004. Using SMS as a way of providing connection and community for first year students. Conference proceedings: 21st ASCILITE Conference, December 5 to 8, Perth, Australia. ASCILITE.

Joshi, M. \& Chugh, R. 2009. New paradigms in the teaching and learning of accounting: Use of educational blogs for reflective thinking. International Journal of education and development using ICT, 5(3):1-10.

Keegan, D. 2005. The incorporation of mobile learning into mainstream education and training. Conference proceedings: Mobile technology: the future of learning in your hands, 4th World Conference on mLearning, October 25 to 28, Cape Town, South Africa. mLearn 2005.

Kukulska-Hulme, A. \& Pettit, J. 2009. Practitioners as innovators: Emergent practice in personal mobile teaching, learning, work and leisure. Edmonton: AU Press, Athabasca University.

Lillie, R.E. 2008. Using a technology-mediated approach to create a practice-feedbackinteraction process for use with accounting courses. Advances in Accounting Education, 9:267.

Louw, W. 2005. Taking the distance out of distance education through the means of mLearning. Conference proceedings: Mobile technology: The future of learning in your hands, 4th World conference on mLearning, October 25 to 28, Cape Town, South Africa. mLearn 2005.

Mildrad, M., Spector, M. \& Davidsen, P. 2003. Model facilitated learning. London: Kogan Page.

Mouly, G.J. 1978. Educational research: the art and science of investigation. Boston: Allyn \& Bacon.

Ng'ambi, D. 2005. Mobile dynamic frequently asked questions (DFAQ) for student and learning support. Conference proceedings: Mobile technology: the future of learning in your hands, 4th World Conference on mLearning, October 25 to 28, Cape Town, South Africa. mLearn.

Prinsloo P. \& Subotzky G.I. 2009. Modeling throughput at Unisa: the key to the successful implementation of ODL. Discussion document. Pretoria, South Africa: Unisa.

Prinsloo, P. \& Van Rooyen, A.A. 2007. Exploring a blended learning approach to improving student success in the teaching of second year accounting. Meditari Accountancy Research, 15(1):51-69.

Sandars, J. 2006. Mobile phones in undergraduate medical education: the tide is beginning to flow. Education for Primary Care, 17(6):549-556.

Sharples, M., Taylor, J. \& Vavoula, G. 2005. Towards a theory of mobile learning. http://66.102.9.104/search?q=cache:Pu_9UCvlh60J:www.mlearn.org.za/CD/papers/Sha rpl. Accessed: 30 January 2008.

Shih, T.K. \& Hung, J.C. 2007. A survey of distance education challenges and technologies. London: Information Science Publishing.

Stead, G. 2005. Moving mobile into the mainstream. Conference proceedings: Mobile technology: the future of learning in your hands, October 25 to 28, Cape Town. mLearn. 
Stone, A. 2005. Blended learning, mobility and retention: supporting first-year university students with appropriate technology. Conference proceedings: Mobile learning anytime everywhere, 2004 mLearn Conference, July 5 to 6, Bracciano, Rome. Learning and Skills Development Agency.

Student Academic Resource Center. 29 June 2009. Success starts at SARC. http://www.sarc.sdes.ucf.edu/sifaculty.php. Accessed: 11 September 2009.

Tinto, V. 1998. Colleges as communities: taking research on student persistence seriously. The Review of Higher Education, 21(2):167-177.

Traxler, J. \& Leach, J. 2006. Innovative and sustainable mobile learning in Africa. Conference proceedings: International workshop on wireless, mobile and ubiquitous technology in education, November 16 to 17, Athens, Greece. IEEE.

Trifonova, A. 2003. Report: Mobile learning - review of the literature. Report number: \# DIT-03-009. Trento, Italy.

Zawacki-Richter, O., Brown, T. \& Delport, R. 2007. Mobile learning - a new paradigm shift in distance education?

http://auspace.athabascau.ca:8080/dspace/bitstream/2149/1258/1/Zawacki-

Richter_Brown_Delport\%20mlearn06.pdf. Accessed: 7 September 2009. 
Van Rooyen

\section{Appendix A}

\begin{tabular}{|c|c|c|}
\hline & $n=230$ & $\begin{array}{l}\text { Frequency } \\
\text { missing }\end{array}$ \\
\hline $\begin{array}{l}\text { Question } 1 \\
\text { Do you own a cell/mobile phone? }\end{array}$ & & 3 \\
\hline - Yes & $95.15 \%$ & \\
\hline - $\quad$ No & $4.85 \%$ & \\
\hline $\begin{array}{l}\text { Question } 2 \\
\text { The ACN202R lecturers sent SMSs to students during the semester. } \\
\text { Did you receive these SMSs? (Tick ONE only) }\end{array}$ & & 10 \\
\hline - Yes & $90.00 \%$ & \\
\hline - $\quad$ No & $10.00 \%$ & \\
\hline $\begin{array}{l}\text { Question } 3 \\
\text { Why do you think you did not receive the SMSs? (Tick ONE only) }\end{array}$ & & 22 \\
\hline - $\quad$ I did receive the SMSs & $88.46 \%$ & \\
\hline - $\quad$ My cellphone number is not on the Unisa system & $4.81 \%$ & \\
\hline $\begin{array}{l}\text { - My cellphone number changed and I did not correct it on the Unisa } \\
\text { system }\end{array}$ & $1.92 \%$ & \\
\hline - $\quad$ Other - please specify & $4.81 \%$ & \\
\hline $\begin{array}{l}\text { Question } 4 \\
\text { Each SMS indicated to you what work to study in a particular week. } \\
\text { Which ONE of the following do you think best describes the workload } \\
\text { per SMS? }\end{array}$ & & 12 \\
\hline - $\quad$ Too much work per SMS & $23.85 \%$ & \\
\hline - $\quad$ Too little work per SMS & $1.38 \%$ & \\
\hline - $\quad$ Can cover work within time allocated per SMS & $64.68 \%$ & \\
\hline - $\quad$ Did not receive the SMSs & $10.09 \%$ & \\
\hline $\begin{array}{l}\text { Question } 5 \\
\text { Are you of the opinion that the SMSs helped you with your studies? } \\
\text { (Tick ONE only) }\end{array}$ & & 11 \\
\hline - Yes & $80.37 \%$ & \\
\hline - $\quad$ No & $9.59 \%$ & \\
\hline - $\quad$ Did not receive the SMSs & $10.05 \%$ & \\
\hline $\begin{array}{l}\text { Question } 6 \\
\text { Do you think it would be helpful if you could send a reply SMS to your } \\
\text { lecturer with regard to study queries? (Tick ONE only) }\end{array}$ & & 11 \\
\hline - Yes & $89.50 \%$ & \\
\hline - No & $10.50 \%$ & \\
\hline $\begin{array}{l}\text { Questions } 7 \\
\text { Lecturers used "sms language" when sending the messages } \\
\text { for example } 4 \text { u } 2 \text { learn. Did you understand all the messages? } \\
\text { (Tick ONE only) }\end{array}$ & & 10 \\
\hline - I understood all the messages & $88.18 \%$ & \\
\hline I had problems understanding some of the messages & $2.27 \%$ & \\
\hline I could not understand the messages at all & - & \\
\hline - $\quad$ I did not receive the SMSs & $9.55 \%$ & \\
\hline $\begin{array}{l}\text { Question } 8 \\
\text { The first SMS was sent on } 20 \text { July } 2007 \text { (registrations closed on } 17 \text { July } \\
\text { 2007). With which ONE of the following do you agree? }\end{array}$ & & 11 \\
\hline - I did not receive the SMSs & $13.70 \%$ & \\
\hline - $\quad$ The first SMS should be sent 1 week later & $18.72 \%$ & \\
\hline The first SMS should be sent 2 weeks later & $7.76 \%$ & \\
\hline - $\quad$ The first SMS was sent at a good time & $56.62 \%$ & \\
\hline - $\quad$ Other - please specify & $3.20 \%$ & \\
\hline
\end{tabular}

Meditari Accountancy Research Vol. 18 No. 12010 : 1-11 